Biogenic outgassing of sulphurous gases from the ocean and subsequent photochemical oxidation contribute an excess of sulphate over that derived from the marine aerosol. We show that excess sulphate, calculated as

$$
\left[\mathrm{SO}_{4}{ }^{2-}\right]_{\text {excess }}=\left[\mathrm{SO}_{4}{ }^{2-}\right]_{\text {total }}-0.12\left[\mathrm{Na}^{+}\right]
$$

(concentrations in Eq. $\mathrm{I}^{-1}$ and assuming that all measured $\mathrm{Na}^{+}$is derived from sea salt), is highly seasonal in character, and annual horizons are well preserved over the whole of the core. This enabled us to determine the chronology to $71 \mathrm{~m}$ depth, and date the bottom of this section as $1844 \pm 5$ years.

$\mathrm{Cl}^{-}$is derived mainly from sea salt. Its profile in the core is also seasonal in character, with peaks that tend to occur in late summer, reflecting the period of minimum sea-ice extent in the Weddell Sea, and therefore maximum source area for the uptake of sea salt. From instrumental meteorological records, Limbert (1974) showed that there were three extended periods of warm or cold weather in the Antarctic Peninsula between 1903 and 1944. During the two 4 year cold periods, when the summer break-up of sea ice in the Weddell Sea is likely to have been reduced, we found that the annual flux of $\mathrm{Cl}^{-}$to the Dolleman Island snow-pack was lower than the average. Conversely, the 3 year warm period showed a peak in the values of annual flux of $\mathrm{Cl}^{-}$. We therefore propose that $\mathrm{Cl}^{-}$can be used as a palaeoclimatic indicator for sea-ice extent.
Extending our chloride data into the latter half of the nineteenth century (before the earliest continuous instrumental records for the Antarctic), we found three distinct peaks in the values of annual flux of $\mathrm{Cl}^{-}$. We suggest that the period $1850-60$ was marked by a decrease in Weddell Sea ice extent (due perhaps to a warm period), followed by an extended period of increased sea ice. There were then two periods of much-reduced sea ice during (approximately) 1885-1890 and 1895-1900, with an intervening period of greatly increased ice coverage. These events are in good agreement with the warm and cold periods which Aristarain and others (1986) identified in the deuterium profile from James Ross Island.

\section{REFERENCES}

Aristarain, A.J., J. Jouzel, and M. Pourchet. 1986. Past Antarctic Peninsula climate (1850-1980) deduced from an ice core isotope record. Climatic Change, 8(1), 69-89.

Limbert, D.W.S. 1974. Variations in the mean annual temperature for the Antarctic Peninsula, 1904-72. Polar Rec., 17(108), 303-306.

Peel, D.A., R. Mulvaney, and B.M. Davison. 1988. Stableisotope / air-temperature relationships in ice cores from Dolleman Island and the Palmer Land plateau, Antarctic Peninsula. Ann. Glaciol., 10, 130-136.

\title{
ANTARCTIC ICEBERGS - PRODUCTION, DISTRIBUTION AND DISINTEGRATION (Abstract)
}

by

Olav Orheim

(Norsk Polarinstitutt, Postboks 158, N-1330 Oslo Lufthavn, Norway)

\section{ABSTRACT}

A programme of systematic iceberg observations was initiated in 1981 by Norsk Polarinstitutt through the SCAR Working Group on Glaciology. Icebergs are recorded every $6 \mathrm{~h}$ and in five length groups: $10-50,50-200,200-500$ and $500-1000 \mathrm{~m}$, and those over $1000 \mathrm{~m}$, which are described individually. Data on more than 100000 icebergs are now on file at Norsk Polarinstitutt, and practically all ships travelling to and from Antarctica participate in the collection of data.

This paper presents the first comprehensive analysis of the iceberg data. The quality of the data set is discussed, with consideration of potential errors in and limitations of the data, and various statistical evaluations. Representative distribution data are presented, and used to determine iceberg production, disintegration and mean residence times, and regional and total Antarctic calving rates.

The incidence of large-scale calving in particular is evaluated, including the remarkably large break-offs in recent years. These exceed both the total annual accumulation on the Antarctic continent and the mean annual calving rate as determined from ship observations.

The results show further: (1) that there are more than 200000 icebergs south of the Antarctic Convergence, (2) that there are large regional differences in iceberg calving rates and iceberg sizes, and (3) that the calving rate from Antarctica is higher than that given in most previous estimates, which implies (4) that the mass balance of the Antarctic ice sheet is not positive as suggested by most recent estimates. 